\title{
KELEKATAN DAN KEPUASAN PERNIKAHAN PADA DEWASA AWAL DI KOTA BANDA ACEH
}

\section{Putri Soraiya, Maya Khairani, Risana Rachmatan, Kartika Sari, Arum Sulistyani}

Program Studi Psikologi, Fakultas Kedokteran, Universitas Syiah Kuala

Jl. Tgk. Tanoh abee Darussalam - Banda Aceh

khairani.maya@gmail.com

\begin{abstract}
Any married couple willing to have satisfaction in their marriage. However, not all couples could achieve satisfaction in their marriage. The quality of marriage was determined by three attachments style; secure attachment style, avoidant attachment style, and anxiety attachments style. This study aimed to investigate the relationship between attachment and marital satisfaction for early adulthood in Banda Aceh. This study used purposive sampling technique and selected 120 subjects (27 male and 93 female), mean of age 30.75 years old, mean of age marriage was 5-7 years, mean of children is 2. Data collected using ENRICH Marital Satisfaction $(E M S)$ which developed by Fowers and Olson (15 statements, $\alpha=.962$ ), and attachment scale (consist of 30 items) compiled by researcher based on the theory of Hazan and Shaver (secure attachment $\alpha=.864$, avoidant $\alpha=$ .877 , anxiety $\alpha=.691$ ). The results showed that there is a positive and significant correlation between secure attachment and marital satisfaction $\left(\mathrm{r}_{\mathrm{xy}}=.455 ; p=.000 ; \mathrm{p}<.001\right)$. The result also showed that there is a negative and significant correlation between insecure attachment and marital satisfaction $\left(r_{x y}\right.$ avoidant $=-.460 ; p=.000 ; p<$ $.001, \mathrm{r}_{\mathrm{xy}}$ anxiety $\left.=-.231 ; \mathrm{p}=.011 ; \mathrm{p}<.05\right)$. Among the three attachment, secure attachment style has the highest significant relationship with marital satisfaction. It meant that the higher score of secure attachment style obtained, the higher satisfaction obtained by these couples.
\end{abstract}

Keywords : attachment; marital satisfaction; early adulthood

\begin{abstract}
Abstrak
Setiap pasangan suami istri akan mendambakan kepuasan dalam pernikahannya. Akan tetapi, tidak semua pasangan suami istri dapat mencapai kepuasan dalam pernikahannya. Kualitas pernikahan individu dengan pasangannya ditentukan oleh tiga tipe kelekatan yaitu tipe kelekatan aman, tipe kelekatan menghindar dan tipe kelekatan cemas. Penelitian ini bertujuan untuk mengetahui hubungan antara kelekatan dengan kepuasan pernikahan pada dewasa awal di Kota Banda Aceh.Teknik pengambilan sampel menggunakan teknik purposive sampling. Sampel pada penelitian ini berjumlah 120 subjek (27 laki-laki dan 93 perempuan) dengan rerata usia 30,75 tahun, rerata usia pernikahan 5-7 tahun dan rerata jumlah anak 2 orang. Alat ukur kepuasan pernikahan pada penelitian ini menggunakan ENRICH Marital Satisfaction (EMS) yang dikembangkan oleh Fowers dan Olson (15 pernyataan) dengan reliabilitas 0,962 . Sementara itu, alat ukur kelekatan disusun sendiri oleh peneliti berdasarkan teori Hazan dan Shaver (30 pernyataan) dengan reliabilitas tipe kelekatan aman 0,864, tipe kelekatan menghindar 0,877, dan tipe kelekatan cemas 0,691. Hasil analisis data menunjukkan bahwa terdapat hubungan positif dan signifikan antara kelekatan secure (kelekatan aman) dengan kepuasan pernikahan $\left(\mathrm{r}_{\mathrm{xy}}=\right.$ $0,455 ; p=0,00 ; \mathrm{p}<0,001)$. Selain itu juga ditemukan bahwa kelekatan insecure (kelekatan menghindar dan kelekatan cemas) berhubungan negatif dan signifikan dengan kepuasan pernikahan $\left(r_{x y}\right.$ kelekatan menghindar $=-0,460$; $; p=0,00 ; \mathrm{p}<0,001$, dan $\mathrm{r}_{\mathrm{xy}}$ kelekatan cemas $\left.=-0,231 ; \mathrm{p}=0,011 ; \mathrm{p}<0,05\right)$. Artinya, semakin tinggi skor tipe kelekatan aman maka tingkat kepuasan pernikahan subjek semakin tinggi.
\end{abstract}

Kata kunci : kelekatan ; kepuasan pernikahan; dewasa awal

\section{PENDAHULUAN}

Setiap individu yang memasuki kehidupan pernikahan akan membawa kebutuhan, harapan, serta keinginannya masingmasing. Suami maupun istri akan mendambakan kehidupan pernikahan yang bahagia dan puas serta berharap dapat memenuhinya dalam institusi pernikahan (Nihayah, Adriani \& Wahyuni, 2013). Pada kenyataannya tidak semua pasangan dapat mencapai kepuasan dalam pernikahan. Adanya hambatan pemenuhan kebutuhan satu atau lebih anggota keluarga akan 
menimbulkan ketidakpuasan (Ardhianita \& Andayani, 2005). Penelitian yang dilakukan oleh Afni dan Indrijati (2011) menjelaskan bahwa dua dari tiga subjek merasakan ketidakpuasan pernikahan karena tidak terpenuhinya aspek material, seksual, dan psikologis dalam rumah tangga. Selain itu, Glenn (dalam Halford, Lizzio, Wilson \& Occhipinti, 2007) dalam penelitiannya mengatakan bahwa kepuasan dalam hubungan pada pasangan suami istri umumnya meningkat saat pernikahan, akan tetapi hal tersebut akan menurun dan sekitar 3-4 persen terjadi perceraian pada saat pernikahan memasuki usia 10 tahun.

Data yang diperoleh peneliti dari Mahkamah Syariah Provinsi Aceh (2014) menunjukkan bahwa di Provinsi Aceh khususnya di Kota Banda Aceh, selama 3 tahun terakhir angka perceraian mengalami peningkatan. Adapun beberapa faktor pemicu perceraian berdasarkan urutan tertinggi antara lain tidak adanya keharmonisan, tidak ada tanggung jawab, gangguan pihak ketiga, cemburu, krisis moral, dan faktor ekonomi. Meningkatnya jumlah kasus perceraian menunjukkan kepuasan pernikahan yang rendah dalam rumah tangga. Hal ini sejalan dengan pendapat Hurlock (1994) bahwa perceraian merupakan puncak dari ketidakpuasan pernikahan yang tertinggi dan terjadi apabila pasangan suami istri sudah tidak mampu lagi saling memuaskan, saling melayani, dan mencari cara penyelesaian masalah yang dapat memuaskan kedua belah pihak.

Kepuasan pernikahan didefinisikan sebagai perasaan yang bersifat subjektif dari pasangan suami istri mengenai kualitas pernikahannya secara menyeluruh (Olson, Defrain \& Skogrand, 2011). Menurut Olson, Fournier dan Druckman (dalam Fowers \& Olson, 1989) terdapat beberapa aspek yang menentukan kepuasan pernikahan yaitu isu kepribadian, komunikasi, pemecahan masalah, manajemen finansial, kegiatan di waktu luang, hubungan seksual, anak dan pengasuhan, keluarga dan teman-teman, kesamaan peran, dan orientasi agama.

Plechaty (dalam Oluwole \& Adebayo, 2008) mengatakan bahwa kepribadian pasangan dan kondisi kehidupan pasangan dalam hal tingkat intimasi dan komunikasi dapat dikatakan sebagai sumber yang paling sering menyebabkan kepuasan atau ketidakpuasan dalam suatu hubungan. Karakteristik kepribadian akan memengaruhi cara pasangan dalam menerima satu sama lain, menilai dan memberi penjelasan mengenai peristiwaperistiwa yang terjadi dalam pernikahan (Bradbury \& Fincham dalam Barelds, 2005).

Salah satu bagian dari kepribadian individu yang berperan dalam menentukan kualitas hubungan individu dengan pasangan adalah kelekatan (Collins \& Read, 1990). Menurut Hazan \& Shaver (1987) kelekatan adalah ikatan emosional yang terjalin dengan figur lekat yang terbentuk sejak masa awal kehidupan individu dan berlanjut ke masa dewasanya dalam rangka pemenuhan rasa aman. Hazan \& Shaver (1987) menyatakan bahwa tipe kelekatan di masa dewasa terbagi tiga yaitu tipe kelekatan aman, tipe kelekatan menghindar dan tipe kelekatan cemas. Kualitas pernikahan individu dengan pasangannya akan ditentukan oleh tiga tipe kelekatan tersebut (Hollist \& Miller, 2005). Penelitian yang dilakukan oleh Banse (2004) menunjukkan hasil bahwa Individu dengan tipe kelekatan aman umumnya memiliki kepuasan pernikahan yang tinggi dibandingkan individu dengan tipe kelekatan tidak aman yaitu cemas dan menghindar.

Tujuan yang ingin dicapai dalam penelitian ini adalah untuk mengetahui hubungan antara kelekatan dengan kepuasan 
pernikahan pada dewasa awal di Kota Banda Aceh. Selain itu, penelitian ini juga bertujuan untuk mengetahui kategorisasi dari kelekatan dan tingkat kepuasan pernikahan subjek penelitian.

Berdasarkan latar belakang masalah di atas, rumusan masalah pada penelitian ini adalah: Apakah ada hubungan antara kelekatan dengan kepuasan pernikahan pada dewasa awal di Kota Banda Aceh? Adapun hipotesis yang diajukan dalam penelitian ini yaitu terdapat hubungan antara kelekatan dengan kepuasan pernikahan pada dewasa awal di Kota Banda Aceh.

\section{METODE}

Penelitian ini menggunakan pendekatan kuantitatif dengan jenis penelitian korelasi. Adapun populasi dalam penelitian ini adalah individu dewasa awal dengan rentang usia 18-40 tahun dan telah menikah selama 10 tahun yang berdomisili di Kota Banda Aceh. Pengambilan sampel dalam penelitian ini menggunakan metode purposive sampling, yaitu teknik penentuan sampel dengan pertimbangan tertentu (Sugiyono, 2014).

Pada penelitian ini peneliti mencari sampel dengan mengunjungi beberapa instansi yang ada di Kota Banda Aceh. Adapun kriteria sampel adalah sebagai berikut :
a. Individu dewasa awal usia 18-40 tahun
b. Berstatus menikah,
c. Usia pernikahan dibawah 10 tahun,
d. Memiliki anak,
e. Pernikahan monogami,
f. Berdomisili di Kota Banda Aceh.

Penelitian ini menggunakan Skala Kelekatan dan Skala Kepuasan Pernikahan sebagai alat pengumpul data. Skala Kelekatan disusun sendiri oleh peneliti mengacu pada tiga tipe kelekatan yang dikembangkan oleh Hazan dan Shaver (1987) yaitu kelekatan aman, kelekatan menghindar dan kelekatan cemas. Berdasarkan tiga tipe kelekatan tersebut, peneliti membuat 27 pernyataan. Hasil uji reliabilitas pada ketiga tipe kelekatan tersebut menunjukkan bahwa reliabilitas tipe kelekatan aman sebesar 0,864, reliabilitas tipe kelekatan menghindar sebesar 0,877 sementara itu reliabilitas tipe kelekatan cemas sebesar 0,691. Skala Kepuasan Pernikahan menggunakan skala yang diadaptasi dari ENRICH Marital Satisfaction (EMS) yang disusun oleh Fowers \& Olson (1993) versi 15 butir pernyataan. Adapun reliabilitas Skala Kepuasan Pernikahan yaitu sebesar 0,962.

Kedua skala tersebut diukur dengan menggunakan penskalaan model Likert dengan lima pilihan jawaban yaitu sangat setuju, setuju, netral, tidak setuju, sangat tidak setuju. Skala ini disajikan dalam bentuk pernyataan favorabel dan unfavorabel. Nilai setiap pilihan jawaban bergerak dari 1-5. Skor untuk setiap pernyataan favorabel yaitu Sangat Setuju diberi nilai 5, Setuju diberi nilai 4, Netral diberi nilai 3, Tidak Setuju diberi nilai 2 dan Sangat Tidak Setuju diberi nilai 1. Pada setiap pernyataan unfavorable yaitu Sangat Setuju diberi nilai 1, Setuju diberi nilai 2, Netral diberi nilai 3, Tidak Setuju diberi nilai 4 dan Sangat Tidak Setuju diberi nilai 5.

Cara menginterpretasi skor total skala kelekatan yaitu dengan menghitung mean dan standar deviasi masing-masing tipe kelekatan, kemudian skor mentah subjek akan diubah menjadi skor $\mathrm{z}$ dengan rumus berikut:

$$
\begin{aligned}
& \mathrm{Z}_{\mathrm{sec}}=\left(\mathrm{X}_{\mathrm{sec}}-\mathrm{M}_{\mathrm{sec}}\right) / \mathrm{S}_{\mathrm{sec}} \\
& \mathrm{Z}_{\mathrm{av}}=\left(\mathrm{X}_{\mathrm{av}}-\mathrm{M}_{\mathrm{av}}\right) / \mathrm{S}_{\mathrm{av}} \\
& \mathrm{Z}_{\mathrm{anx}}=\left(\mathrm{X}_{\mathrm{anx}}-\mathrm{M}_{\mathrm{anx}}\right) / \mathrm{S}_{\mathrm{anx}}
\end{aligned}
$$


Skor z yang diperoleh dari masing-masing tipe kelekatan akan dibandingkan satu sama lain. Skor $\mathrm{z}$ tertinggi dari salah satu tipe kelekatan mewakili tipe kelekatan subjek. Adapun cara menginterpretasi skor total pada skala kepuasan pernikahan yaitu dengan melihat dari besarnya skor total yang diperoleh. Semakin tinggi skor skala kepuasan pernikahan maka semakin tinggi kepuasan pernikahan, begitu pula sebaliknya, semakin rendah skor yang diperoleh maka semakin rendah kepuasan pernikahan subjek. Skor total subjek akan diinterpretasi dengan menggunakan rumus berikut:

EMS score $=$ PCT $-[(.40 \times$ PCT $)($ ID $\times .01)]$

Keterangan:

EMS = ENRICH Marital Satisfaction

$\mathrm{PCT}=$ Percentile score for individual marital satisfaction scale

ID = Percentile score for individual idealistic distortion scale

Analisis data dalam penelitian ini menggunakan teknik analisis korelasi Spearman. Peneliti menggunakan teknik Spearman karena salah satu variabel tidak berdistribusi normal. Teknik ini digunakan untuk mengetahui hubungan antara kelekatan dengan kepuasan pernikahan pada dewasa awal di Kota Banda Aceh.

\section{HASIL DAN PEMBAHASAN}

Hasil analisis data menunjukkan bahwa terdapat hubungan yang positif dan signifikan antara kelekatan secure (kelekatan aman) dengan kepuasan pernikahan pada dewasa awal di Kota Banda Aceh, $\left(\mathrm{r}_{\mathrm{xy}}=0,455 ; p \leq 0,000\right)$. Selain itu juga ditemukan bahwa terdapat hubungan negatif dan signifikan antara kelekatan insecure (kelekatan cemas dan kelekatan menghindar) dengan kepuasan pernikahan pada dewasa awal di Kota Banda Aceh. (kelekatan menghindar $\mathrm{r}_{\mathrm{xy}}=$ 0,$460 ; p \leq 0,000$. Kelekatan cemas $\mathrm{r}_{\mathrm{xy}}=$ -
$0,231 ; p \leq 0,011)$. Artinya semakin tinggi skor tipe kelekatan aman maka tingkat kepuasan pernikahan subjek semakin tinggi. Sebaliknya, semakin rendah skor tipe kelekatan aman maka tingkat kepuasan pernikahan subjek semakin rendah.

Hasil penelitian ini sejalan dengan beberapa hasil penelitian sebelumnya yang menyatakan bahwa kelekatan secure (kelekatan aman) berhubungan positif dengan kepuasan pernikahan. Sementara itu, kelekatan insecure (kelekatan menghindar dan kelekatan cemas) berhubungan negatif dengan kepuasan pernikahan (Banse, 2004; Hirsberger, Srivastava, Marsh, Cowan \& Cowan, 2009; Mohammadi, Zarei \& Narenji, 2015). Individu yang memiliki tipe kelekatan aman memiliki kepuasan pernikahan yang lebih tinggi dibandingkan dengan individu yang memiliki tipe kelekatan tidak aman yaitu tipe kelekatan cemas dan menghindar. (Banse, 2004; Hirsberger, dkk, 2009).

Hasil dari penelitian ini menunjukkan bahwa $40 \%$ dewasa awal memiliki tipe kelekatan aman, 35\% dewasa awal memiliki tipe kelekatan menghindar dan $25 \%$ dewasa awal memiliki tipe kelekatan cemas. Hal ini bisa disebabkan oleh beberapa faktor diantaranya adalah tipe kelekatan yang digunakan oleh pengasuh utama individu pada masa bayi. Bowbly (dalam Bjorklund \& Bee, 2009) menjelaskan bahwa kelekatan adalah proses seumur hidup, dan kualitas hubungan individu dengan pengasuh utamanya merupakan dasar terbentuknya kelekatan pada masa selanjutnya, termasuk kelekatan romantis, dimana dalam hal ini terjadi pada pasangan suami istri. Pernyataan tersebut diperkuat oleh Ainsworth (dalam Iriani \& Ninawati, 2005) yang menyatakan bahwa kepekaan pengasuh merupakan penentu kualitas kelekatan anak. Saat pengasuh atau orang tua memberikan respon yang baik, tepat dan konsisten terhadap kebutuhan 
anak, maka anak akan mengembangkan kelekatan yang aman. Demikian pula sebaliknya, pengasuh atau orang tua yang tidak dapat diandalkan ketika anak membutuhkan sesuatu akan mengembangkan kelekatan yang tidak aman.

Berdasarkan hasil analisis measures of association pada tiga tipe kelekatan menunjukkan bahwa pada penelitian ini sumbangan efektif tipe kelekatan aman terhadap kepuasan pernikahan adalah sebesar R Square $\left(\mathrm{R}^{2}\right)=0,260$, artinya, terdapat $26,0 \%$ pengaruh tipe kelekatan aman terhadap kepuasan pernikahan, sementara $74,0 \%$ dipengaruhi oleh faktorfaktor lain. Sementara itu, sumbangan efektif tipe kelekatan menghindar terhadap kepuasan pernikahan adalah sebesar $\mathrm{R}$ Square $\left(\mathrm{R}^{2}\right)=0,313$, artinya terdapat $31,3 \%$ pengaruh tipe kelekatan menghindar terhadap kepuasan pernikahan, sementara $68,7 \%$ dipengaruhi oleh faktor-faktor lain. Selanjutnya sumbangan efektif tipe kelekatan cemas terhadap kepuasan pernikahan adalah sebesar $\mathrm{R}$ Square $\left(\mathrm{R}^{2}\right)=$ 0,102 , artinya, terdapat $10,2 \%$ pengaruh tipe kelekatan cemas terhadap kepuasan pernikahan, sementara $89,8 \%$ dipengaruhi oleh faktor-faktor lain.

Menurut Duvall \& Miller (1985) terdapat beberapa faktor yang dapat mendukung kepuasan pernikahan yang tinggi pada individu dewasa awal yang telah menikah dapat berupa karakteristik masa lalu dan karakteristik masa kini. Karakteristik masa lalu meliputi kebahagiaan dalam pernikahan orang tua, disiplin, kedekatan, adanya pendidikan seks yang memadai dari orang tua, masa kanak-kanak dan pendidikan, sedangkan karakteristik masa kini meliputi kehidupan seksual, kepuasan terhadap tempat tinggal, pendapatan keluarga, tingkat kesetaraan, komunikasi, kehidupan sosial, ekspresi kasih sayang dan kepercayaan
Pada penelitian ini dapat dilihat beberapa faktor dari karakteristik masa lalu dan masa kini yang memiliki sumbangsih terhadap kepuasan pernikahan diantaranya adalah faktor pendidikan. Berdasarkan data demografi subjek, sekitar $64 \%$ subjek memiliki latar belakang pendidikan S-1 dan S-2. Latar belakang pendidikan yang tinggi tersebut akan memudahkan proses penyesuaian diri individu dalam kehidupan pernikahannya sehingga berpengaruh terhadap kepuasan pernikahan (Duvall \& Miller, 1985).

Adapun beberapa faktor masa kini yang mendukung kepuasan pernikahan yang tinggi diantaranya adalah kehidupan seksual, dimana pasangan suami istri saling menikmati kehidupan seksual yang dijalaninya (Duvall \& Miller, 1985). Terkait dengan kehidupan seksual tersebut, sebagian besar subjek dalam penelitian ini memiliki kehidupan seksual yang memuaskan bersama pasangannya. Hal ini dilihat dari rata-rata skor subjek pada pernyataan nomor 11 yang mengungkap aspek hubungan seksual. Faktor selanjutnya yang mendukung kepuasan pernikahan yang tinggi adalah tingkat kesetaraan. Menurut Duvall \& Miller (1985), tingkat kesetaraan yaitu tidak ada dominasi dari salah satu pasangan suami istri dimana setiap keputusan yang diambil dalam kehidupan pernikahan dilakukan dengan kesepakatan yang setara antara suami istri mapun sebaliknya. Ditinjau dari faktor tersebut, sebagian besar subjek juga merasa puas terhadap tingkat kesetaraan mereka bersama pasangannya. Hal ini dilihat dari rata-rata skor yang diperoleh subjek pada pernyataan nomor 3 yang mengungkap aspek tingkat kesetaraan.

Selain faktor kehidupan seksual dan kesetaraan peran, faktor komunikasi juga berperan penting dalam mencapai pernikahan yang memuaskan. Hal tersebut senada dengan pernyataan Sadarjoen 
(dalam Wardhani, 2012) bahwa pernikahan yang baik ditandai oleh komunikasi yang baik, keintiman, kedekatan, seksualitas, serta kepercayaan, dimana semua hal tersebut sangat penting untuk menjalin hubungan pernikahan yang memuaskan. Berdasarkan rata-rata skor subjek pada pernyataan nomor 4, 5 dan 6 yang mengungkap aspek komunikasi ditemukan bahwa subjek penelitian ini merasa puas terhadap hubungan komunikasi dengan pasangan mereka.

Olson, Fournier dan Druckman (dalam Fowers \& Olson, 1989) menambahkan bahwa adanya anak dalam kehidupan pernikahan pasangan suami istri juga berpengaruh terhadap kepuasan pernikahan. Pada penelitian ini diketahui bahwa sebagian besar subjek merasa puas terhadap kehadiran anak dalam kehidupan pernikahan. Hal tersebut dilihat dari ratarata skor subjek pada pernyataan nomor 12 yang mengungkap aspek anak dan pengasuhan.

Berdasarkan tinjauan diatas, pada penelitian ini sebanyak $85,83 \%$ subjek memiliki kepuasan pernikahan yang tergolong tinggi. Sementara itu, sebanyak $4,16 \%$ subjek memiliki kepuasan pernikahan yang tergolong sedang dan sebanyak $10 \%$ subjek memiliki kepuasan pernikahan yang tergolong rendah. Dengan demikian, dapat dikatakan bahwa sebagian besar subjek memiliki tingkat kepuasan pernikahan yang tergolong tinggi.

\section{KESIMPULAN}

Berdasarkan hasil analisis data menunjukkan bahwa terdapat hubungan positif dan signifikan antara kelekatan secure (aman) dengan kepuasan pernikahan. Selain itu juga ditemukan bahwa kelekatan insecure (menghindar dan cemas) berhubungan negatif dan signifikan dengan kepuasan pernikahan pada dewasa awal di
Kota Banda Aceh, adapun hubungan signifikan yang paling kuat diantara tiga tipe kelekatan adalah tipe kelekatan aman. Hal tersebut mengindikasikan bahwa semakin tinggi skor tipe kelekatan aman maka tingkat kepuasan pernikahan subjek semakin tinggi.

Pada penelitian ini dapat dilihat beberapa faktor yang diprediksi memiliki pengaruh terhadap kepuasan pernikahan yaitu masa kanak-kanak, pendidikan, kehidupan seksual, tingkat kesetaraan, komunikasi, dan ekspresi kasih sayang.

\section{DAFTAR PUSTAKA}

Afni, N., \& Indrijati, H. (2011). Pemenuhan aspek-aspek kepuasan perkawinan pada istri yang menggugat cerai suami. Insan, 13(3), 176-184.

Ardhianita, I., \& Andayani, B. (2005). Kepuasan pernikahan ditinjau dari berpacaran dan tidak berpacaran. Jurnal Psikologi, 32(2), 101-111.

Banse, R. (2004). Adult attachment and marital satisfaction: Evidence dyadic configurations effects. Journal of social and personal relationships, 21(2), 273-282.

Barelds, D. P. H. (2005). Self and partner personality in intimate relationships. European Journal of Personality, 19, 501-518.

Bjorklund, B. R., \& Bee, H. L. (2009). The journey of adulthood: Sixth editions. London: Prentice Hall.

Collins, N. L, \& Read, S. J. (1990). Adult attachment, working models, and relationship quality in dating couples. Journal of personality and social psychology, 58(4), 644-663. 
Duvall, E. M., \& Miller. B. C. (1985). Marriage and the family development: Sixth edition. New York: Harper \& Row Publisher, Inc.

Fowers, B. J., \& Olson, D. (1989). ENRICH marital inventory: A discriminant validity and crossvalidity assessment. Journal of marital and family therapy, 15(1), 6579.

Fowers, B. J., \& Olson, D. H. (1993). ENRICH Marital satisfaction scale: A brief research and clinical tool. Journal of Family Psychology, 7(2), 176-185.

Halford, W. K., Lizzio, A., Wilson, K. L., \& Occhipinti. (2007). Does working at your marriage help? Couple relationship self regulation and satisfaction in first 4 years of marriage. Journal of Family Psychology, 21(2), 185-194.

Hazan, C., \& Shaver, P. R. (1987). Romantic love conceptualized as an attachment process. Journal of personality and social psychology, 52(3), 511-524.

Hirsberger, G., Srivastava, S., \& Marsh, P. (2009). Attachment, marital satisfaction and divorce during the first fifteen years of parenthood. Pers Relatsh, 16(3), 401-420.

Hollist, C. S., \& Miller, R. B. (2005). Perceptions of attachment style and marital quality in midlife marriage. Family Relations, 54(1), 46-57.

Hurlock, E. B. (1994). Psikologi perkembangan: suatu pendekatan sepanjang rentang kehidupan. Jakarta: Erlangga.
Iriani, F., \& Ninawati. (2005). Gambaran kesejahteraan psikologis pada dewasa muda ditinjau dari pola attachment. Jurnal Psikologi, 3(1), 44-64.

Mahkamah Syariah Aceh. Informasi data perceraian di Aceh tahun 2012-2014. Diakses pada tanggal 22 Maret 2015 melalui website http://www.msaceh.go.id/

Mohammadi, K., Zarei, E., \& Narenji, F. K. D. (2015). The study of the relationships between the attachment style and marital satisfaction in married employees of Landeh town. South Journal of Educational Psychology and counseling, 2(1), 815.

Nihayah, Z., Adriani, Y \& Wahyuni, Z.I. (2013). Conference proceedings of AICIS XII: Peran religiusitas dan faktor-faktor psikologis terhadap kepuasan pernikahan.

Olson, D. H., Defrain, J., \& Skogrand, L. (2011). Marriages and families; intimacy, diversity and strengths: Seven edition. New York: McGrawHill Companies. Inc.

Oluwole., \& Adebayo, D. (2008). Marital satisfaction: connections of self disclosure, sexual self- efficacy and spirituality among Nigerian women. Pakistan Journal of Social Sciences, 5(5), 464-469.

Sugiyono. (2014). Metode penelitian kuantitatif kualitatif dan $R \& D$. Bandung: Alfabeta.

Wardhani, N. A. K. (2012). Self disclosure dan kepuasan perkawinan pada usia awal perkawinan. Calyptra: Jurnal Ilmiah Mahasiswa Universitas Surabaya, 1(1). 
